\title{
Reduced male reproductive capacity in mice with high genetic potential for post-weaning growth
}

\author{
Trish Berger, C. C. Calvert and G. E. Bradford \\ Department of Animal Science, University of California, Davis, CA 95616, USA
}

\begin{abstract}
Summary. Male reproductive capacity was examined in 5 lines of mice which differed markedly in mature body weight $(30-73 \mathrm{~g})$ due to selection for growth and/or substitution of the high growth gene $(h g)$. Testes weight ranged from $0.75-0.77 \%$ of body weight in control lines to $\mathbf{0 . 3 3 \%}$ in the largest mice which had the $h g$ gene in a growth selected background. Both selection for growth and the hg gene in a control background reduced absolute testes size $(0.200$ and $0.207 \mathrm{~g} v s 0.236$ and $0.228 \mathrm{~g}$ in control lines) as well as relative testes size although body weight was increased by at least $50 \%$. Although the combination of growth background and $h g$ gene reduced sperm production per $\mathrm{g}$ testis compared to the outbred control, the primary cause of reduced sperm production per mouse in lines containing either the growth background or the $h g$ gene alone was reduced absolute testes size. At 24 , but not at 11 , weeks of age, the $h g$ gene reduced sperm motility. In these lines, high genetic potential for post-weaning growth was associated with decreased male reproductive capacity.
\end{abstract}

Keywords: testis size; spermatogenesis; body weight; mice

\section{Introduction}

Lowered fertility has often accompanied selection for increased growth (Roberts, 1979). Although the low libido of the heavier males was believed to be the cause of lowered fertility in one line of mice with fertility problems (Fowler \& Edwards, 1960), the effects of selection for growth on male reproductive parameters are not well understood and effects on testes size have been variable (Phillips \& Zeller, 1943; Allrich et al., 1981; Eisen \& Johnson, 1981; Schinckel et al., 1983).

A correlation between testicular weight (i.e. both testes) in the male and ovulation rate in the female occurs among lines or breeds of mice, pigs and sheep (Land, 1973; Land \& Carr, 1975; Eisen \& Johnson, 1981; Schinckel et al., 1983) although testes were smaller in a strain of mice selected for exogenous gonadotrophin-induced ovulation rate (Wolfe et al., 1981). The correlation between male and female reproduction occurs when selection is based on either ovulation rate or testicular weight (Islam et al., 1976); this suggests that the same genes affect the gonads in the male and the female (Wolfe et al., 1981). An increase in ovulation rate has generally accompanied selection for increased body size (reviewed by Roberts, 1979). Selection for large litter size increased body weight and testicular weight in mice although differences in pubertal testicular weight were not significant when adjusted for body weight (Eisen \& Johnson, 1981). Previously, reduced fertility and increased ovulation rate were observed in lines of mice with high genetic potential for growth (Bradford, 1971; Dilts, 1988). The current study examined male reproductive capacity in these lines.

\section{Materials and Methods}

Mice. Growth lines $\mathrm{GH}$ and $\mathrm{Gh}$ and the outbred control line $\mathrm{C}$ and growth line $\mathrm{Ch}$ and its control line $\mathrm{CH}$ are briefly described in Table 1 (Bradford, 1971; Bradford \& Famula, 1984; Calvert et al., 1986). 
Table 1. Description of mouse lines studied

\begin{tabular}{lcccc}
\hline Line & Background & $\begin{array}{c}h g \\
\text { gene }\end{array}$ & Selection & $\begin{array}{c}\text { Mature } \\
\text { body } \\
\text { weight } \\
(\mathrm{g})^{*}\end{array}$ \\
\hline $\mathrm{C}$ & Outbred $\dagger$ & No & Random & $29 \cdot 79^{\mathrm{a}}$ \\
GH & Outbred $\dagger$ & No & Growth & $51 \cdot 04^{\mathrm{b}}$ \\
Gh & Outbred $\dagger$ & Yes & Growth & $72 \cdot 56^{\mathrm{c}}$ \\
$\mathrm{CH}$ & B6 $\ddagger$ & No & na & $31 \cdot 46^{\mathrm{a}}$ \\
$\mathrm{Ch}$ & B6 $\ddagger$ & Yes & na & $47 \cdot 82^{\mathrm{d}}$ \\
\hline
\end{tabular}

*Values represent the means for 23 males from line $\mathrm{C}$ at 14 weeks of age, and 16 males from line $\mathrm{GH}, 27$ males from line $\mathrm{Gh}, 35$ males from line $\mathrm{CH}$, and 36 males from line $\mathrm{Ch}$ at 11 weeks of age.

†All 3 lines have the same outbred background.

$\$ 87 \cdot 5 \% \mathrm{C} 57 \mathrm{BL} / 6,12 \cdot 5 \%$ outbred.

abcd Values in the same row with no common superscript are different, $P<0.05$.

Males were separated from females for a minimum of 2 days before evaluation of sperm-producing capacity. Males from contemporary generations 7, 8, 11 and 11 of Lines $\mathrm{Gh}, \mathrm{GH}, \mathrm{Ch}$ and $\mathrm{CH}$, respectively, were examined at 11 weeks of age. Litter productivity per mating pair, the number of offspring born within 35 days of pairing, was recorded for each male. The percentage of males siring a litter within 35 days of mating and the average number of young per litter born were recorded for 4 additional generations from each line. Line $\mathrm{C}$ males from generation 79 were examined at 14 weeks of age. Line $\mathrm{Ch}$ and $\mathrm{CH}$ males from generation 9 were examined at 24 weeks of age.

Experimental procedures. Mice were killed by cervical dislocation and immediately weighed. Testes and, in some cases, the abdominal fat pads associated with the spermatic cords were dissected and weighed. Relative testicular weight was the combined weight of the testes expressed as a percentage of body weight. Fat pads were stored at $-17^{\circ} \mathrm{C}$ until determination of dry weight by heating at $102^{\circ} \mathrm{C}$ to a constant weight. A short segment of the vas deferens was placed in a warm $\left(37^{\circ} \mathrm{C}\right)$ drop of phosphate-buffered saline and spermatozoa were allowed to disperse for $5 \mathrm{~min}$. Motility was estimated subjectively at $\times \mathbf{4 0 0}$ by a 'blind' observer using phase-contrast optics. Both the percentage of spermatozoa exhibiting tail movement (percentage motile spermatozoa) and the percentage of spermatozoa exhibiting forward movement (percentage progressively motile spermatozoa) were recorded. Sperm production was evaluated using testicular homogenates. Testes were homogenized in $5 \mathrm{ml}$ homogenization buffer (Amann \& Lambiase, 1969) and the homogenizer rinsed with an additional $5 \mathrm{ml}$ homogenization buffer. Spermatids were then counted with a haemocytometer until counts from at least 3 of 4 haemocytometer chambers were within $10 \%$ of each other. The average of the 3 counts was corrected for dilution and used for analysis.

Statistical analysis. Data were subjected to analysis of variance after transformation of percentage data to the arcsin square root using SAS (SAS Institute, Inc., Cary, NC). Differences amongst means were evaluated with Bonferroni $t$ tests. The allometric relationship between testicular weight and body weight was determined by linear regression after logarithmic transformation of both measures. This relationship was determined for $\mathrm{Lines} \mathrm{CH}, \mathrm{Ch}, \mathrm{C}$, $\mathrm{GH}$ and $\mathrm{Gh}$ individually and combined.

\section{Results}

\section{Males at 11 weeks}

Absolute testicular size at 11 weeks of age was decreased by both the growth backgound (GH) and the $h g$ gene in the control background $(\mathrm{Ch})$ compared with the controls $(\mathrm{C}$ and $\mathrm{CH}$ respectively), despite the increased body weight in the lines selected for growth (Table 2). The absolute testicular size in the presence of the $h g$ gene in the growth background was the same as that in both control lines. Relative testicular weight was similar in the two control lines and was depressed by the $h g$ gene ( $\mathrm{Ch} v s \mathrm{CH}$; Gh vs GH; Fig. 1), by the growth background (GH vs $\mathrm{C}$ ), and further by both genetic factors in combination ( $\mathrm{Gh} v \mathrm{C}$ ). Amongst these lines, testicular size did not exhibit a significant allometric relationship. 
Table 2. Male reproductive capacity in Lines $\mathrm{CH}, \mathrm{Ch}, \mathrm{GH}, \mathrm{Gh}$ and $\mathrm{C}$

\begin{tabular}{|c|c|c|c|c|c|}
\hline & \multicolumn{5}{|c|}{ Line } \\
\hline & $\mathrm{CH}^{*}$ & $\mathrm{Ch}^{*}$ & $\mathrm{GH}^{*}$ & $\mathrm{Gh}^{*}$ & $\mathrm{C}^{*}$ \\
\hline Testicular wt (g) & $\begin{array}{c}0.236 \pm \\
0.006^{2}\end{array}$ & $\begin{array}{r}0.200 \pm \\
0.005^{\mathrm{b}}\end{array}$ & $\begin{array}{c}0.207 \pm \frac{t}{0} \\
0.008^{\mathrm{b}}\end{array}$ & $\begin{array}{c}0.238 \pm \\
0.006^{\mathrm{a}}\end{array}$ & $\begin{array}{c}0.228 \pm \\
0.007^{\mathrm{a}}\end{array}$ \\
\hline Relative testicular wt (as \% of body wt) & $\begin{array}{c}0.75 \pm \\
0.01^{\mathrm{a}}\end{array}$ & $\begin{array}{c}0.42 \pm \\
0.01^{\mathrm{b}}\end{array}$ & $\begin{array}{c}0.41 \pm \\
0.01^{\mathrm{b}}\end{array}$ & $\begin{array}{c}0 \cdot 33 \pm \\
0.02^{c}\end{array}$ & $\begin{array}{c}0.77 \pm \\
0.01^{\mathrm{a}}\end{array}$ \\
\hline Spermatids/mouse $\left(\times 10^{-6}\right)$ & $\begin{array}{c}344 \pm \\
17^{\mathrm{ab}}\end{array}$ & $\frac{281 \pm}{16^{\mathrm{c}}}$ & $\begin{array}{c}309 \pm \\
25^{\mathrm{ac}}\end{array}$ & $\begin{array}{c}309 \pm \\
19^{\mathrm{ac}}\end{array}$ & $\begin{array}{l}386 \pm \\
19^{b}\end{array}$ \\
\hline Spermatids/g testis $\left(\times 10^{-6}\right)$ & $\begin{array}{c}1468 \pm \\
69^{\mathrm{ab}}\end{array}$ & $1406 \pm$ & $\begin{array}{c}1511 \pm \\
96^{\mathrm{ab}}\end{array}$ & $\begin{array}{r}1293 \pm \\
74^{\mathrm{a}}\end{array}$ & $\underset{80^{\mathrm{b}}}{1694 \pm}$ \\
\hline Litter productivity/mating pair & $\begin{array}{c}10 \cdot 9 \pm \\
0 \cdot 6^{\mathrm{a}}\end{array}$ & $\begin{array}{c}10 \cdot 0 \pm \\
0.6^{\mathrm{a}}\end{array}$ & $\begin{array}{l}9.9 \pm \\
0.9^{\mathrm{a}}\end{array}$ & $\begin{array}{l}5 \cdot 9 \pm \\
0.7^{b}\end{array}$ & \\
\hline Abdominal fat $\uparrow$ (wet wt) (g) & $\begin{array}{c}0.3188 \pm \\
0.0184^{\mathrm{a}}\end{array}$ & $\begin{array}{c}0.5043 \pm \\
0.0181^{\mathrm{b}}\end{array}$ & & & \\
\hline Abdominal fat $†$ (dry wt) (g) & $\begin{array}{r}0.0265 \pm \\
0.0002^{\mathrm{a}}\end{array}$ & $\begin{array}{c}0.0423 \\
0.0002^{\mathrm{b}}\end{array}$ & & & \\
\hline
\end{tabular}

*Values represent the means \pm s.e.m. for 35 males from Line $\mathrm{CH}, 36$ males from Line $\mathrm{Ch}, 16$ males from Line $\mathrm{GH}$ and 27 males from Line $\mathrm{Gh}$ at 11 weeks of age and 23 males from Line $\mathrm{C}$ at 14 weeks of age.

†The abdominal fat pads associated with spermatic cords.

${ }^{\mathrm{abc}}$ Values in the same row with no common superscripts are different, $P<0.05$.

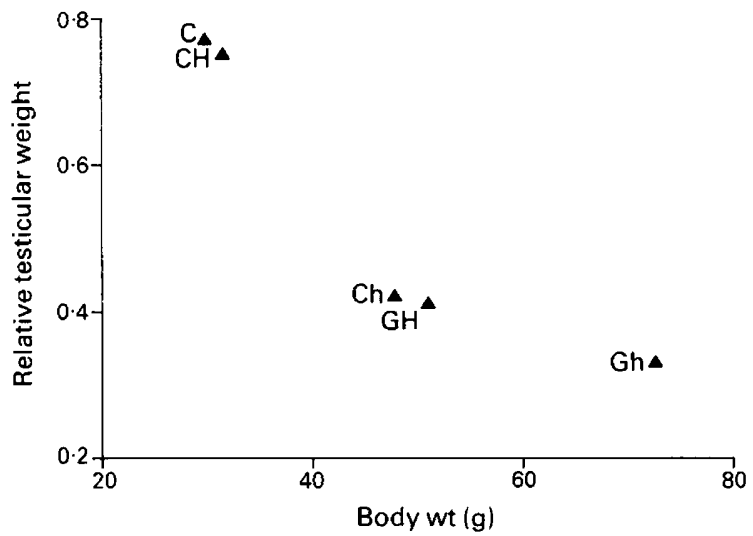

Fig. 1. Relationship between the relative testicular weight (as $\%$ of body weight) and body weight $(\mathrm{g})$ for the 5 mouse lines.

The $h g$ gene appeared to have a slight effect on spermatogenesis measured as spermatids/g testis in the control and growth backgrounds but the effect was not significant $(P<0 \cdot 15)$. However, the $h g$ gene in combination with the growth background reduced sperm production/g testis compared to the outbred control ( $\mathrm{Gh} v s \mathrm{C}$ ). The percentage of spermatozoa that were motile and the percentage of spermatozoa that were progressively motile were similar amongst lines. The $h g$ gene decreased sperm production per mouse in the control background ( $\mathrm{Ch} v \mathrm{CH}$ ) but not significantly in the growth background ( $\mathrm{Gh} v s \mathrm{GH}$ ). However, the growth background reduced sperm production per mouse relative to the outbred control (GH vs $\mathrm{C} ; P<0.05$ ).

The $h g$ gene increased the amount of abdominal fat associated with the spermatic cords in the control background $(P<0.001)$ but the amount as a percentage of body weight was not different. The dry weight of the fat was $8.3 \%$ and $8.4 \%$ of the wet weight for mice in Lines $\mathrm{CH}$ and $\mathrm{Ch}$, respectively, suggesting the composition of the fat was similar. 


\section{Males at 24 weeks}

The $h g$ gene had effects in 24-week-old Ch males similar to those in 11 -week-old males. Testicular weight had increased between 11 and 24 weeks in $\mathrm{CH}$ and $\mathrm{Ch}$ males but the $h \mathrm{~g}$ gene continued to be responsible for testes smaller in absolute weight as well as relative to body weight (Table 3 ). The relative testicular weights for the two lines at 24 weeks were quite close to the values at 11 weeks of age $(0.70 \%$ and $0.75 \%$ respectively for $\mathrm{CH}$, and $0.41 \%$ and $0.42 \%$ for $\mathrm{Ch})$. The $h g$ gene did not significantly lower sperm production/g testis $(P=0.15)$ but did reduce sperm production per mouse. By 24 weeks of age, the percentage of motile spermatozoa was depressed by the $h g$ gene $(P<0.05)$; the percentage of progressively motile spermatozoa appeared to be affected $(P<0 \cdot 10)$.

Table 3. Male reproductive capacity in Lines $\mathrm{CH}$ and $\mathrm{Ch}$ at 24 weeks of age

\begin{tabular}{lcc}
\hline & \multicolumn{2}{c}{ Line } \\
\cline { 2 - 3 } & $\mathrm{CH}$ & $\mathrm{Ch}$ \\
\hline Mouse wt (g) & $36 \cdot 45 \pm 0 \cdot 51$ & $54 \cdot 41 \pm 0 \cdot 52^{*}$ \\
Testicular wt (g) & $(28)$ & $(27)$ \\
& $0 \cdot 255 \pm 0 \cdot 008$ & $0 \cdot 221 \pm 0 \cdot 008 \dagger$ \\
Relative testicular wt (as & $0 \cdot 70 \pm 0 \cdot 02$ & $0 \cdot 41 \pm 0 \cdot 02^{*}$ \\
$\%$ of body wt) & $(28)$ & $(27)$ \\
Spermatids/g testis & $1502 \pm 80$ & $1338 \pm 80$ \\
$\left(\times 10^{-6}\right)$ & $(28)$ & $(27)$ \\
Spermatids/mouse & $380 \pm 20$ & $302 \pm 20 \dagger$ \\
$\left(\times 10^{-6}\right)$ & $(28)$ & $(27)$ \\
$\%$ Motile spermatozoa & $85 \pm 6$ & $60 \pm 6 \ddagger$ \\
& $(12)$ & $(12)$ \\
\% Progressively motile & $68 \pm 7$ & $51 \pm 7$ \\
spermatozoa & $(12)$ & $(12)$ \\
\hline
\end{tabular}

Values represent the mean \pm s.e.m. for the no. of males indicated in parentheses.

*Different from value for males from the $\mathrm{CH}$ line, $P<0.001$.

tDifferent from value for males from the $\mathrm{CH}$ line, $P<0.01$.

\$Different from value for males from the $\mathrm{CH}$ line, $P<0.05$.

\section{Fertility}

Litter productivity per mating pair, an estimate of the combined fertility of male and female, was reduced by the $h g$ gene in the growth background (Table 2). In 4 additional generations for each line, the percentages of females littering within 35 days of pairing were $94,79,90$ and $68 \%$ for Lines $\mathrm{CH}, \mathrm{Ch}, \mathrm{GH}$ and $\mathrm{Gh}$ respectively (means of $87-162$ females). However, the average litter size of those that littered within this interval varied little amongst lines with the litter size for mice in Line $\mathrm{Gh}$ being slightly smaller than that for Line $\mathrm{Ch}(P<0.05 ; 11 \cdot 0,11.3,10.5$ and 9.9 for Lines $\mathrm{CH}, \mathrm{Ch}, \mathrm{GH}$ and $\mathrm{Gh}$, respectively).

\section{Discussion}

Selection for body weight or the presence of the $h g$ gene in the control background resulted in decresed absolute testicular weight. All 3 growth lines had decreased testicular weight relative to 
body weight in this study. This observation is in contrast to previous selection experiments which showed positive correlations among growth, ovulation rate or litter size and testicular size (Joakimsen \& Baker, 1977; Eisen \& Johnson, 1981).

These results are consistent with our observations on the fertility of these lines. Males and females both contributed to the subfertility of mice carrying the hg gene (Bradford \& Famula, 1984; Famula et al., 1986). Decreased fertility of the Gh males has been confirmed by the higher pregnancy rate after mating of $\mathrm{Gh}$ females to males of a different line compared with the pregnancy rate after confirmed mating to Gh males (Dilts, 1988). Pairs of mice from the 3 growth lines are known to have a short fertile life. The relatively small testicular size and reduced sperm production probably contribute to the reduced fertility initially. The decreased sperm motility seen in older mice may also contribute to the reduced fertile life of the mice.

Fat in the vicinity of the spermatic cords might differentially affect temperature regulation of the testes and spermatogenic efficiency. Therefore, the size of the fat pad most intimately associated with the spermatic cords was examined. Although absolute amounts of fat were greater in the $\mathrm{Ch}$ mice than in the $\mathrm{CH}$ mice, amounts as a percentage of body weight did not differ, consistent with the absence of a significant effect on spermatogenic efficiency.

Testicular weight relative to body weight varies widely among strains and species (Setchell, 1978) and the genes involved are not well understood. A significant negative allometric relationship for testicular size has been reported (Kenagy \& Trombulak, 1986). However, testicular size varies greatly from that predicted by the allometric equation $(0 \cdot 1-8 \cdot 0 \times$ the predicted value) and factors in addition to body weight were suggested to be important.

The decreased weight of the testes in the $\mathrm{Ch}$ males relative to the $\mathrm{CH}$ males may relate to the previously observed negative response of testicular weight to selection for lean growth in rats (Allrich et al., 1981) and of pubertal testicular weight to selection for lean growth in pigs (Schinckel et al., 1983). However, since the percentage body fat does not differ significantly between $\mathrm{CH}$ and Ch males or between GH and Gh males (Calvert et al., 1985, 1986), a requirement for a minimal amount of body fat for gonadal development cannot be the cause of reduced testicular size (Frisch, 1980).

In other studies examining testicular size in mice and rats, malnutrition and a number of recessive genes which caused infertility reduced testicular size as well as body size (Campbell et al., 1977; Glass et al., 1979; Chubb \& Nolan, 1985). Interestingly, the reduced male fertility and reduced duration of male fertility in one line, a line with reduced serum growth hormone concentrations and reduced serum somatomedin, was alleviated by incorporation and expression of a growth hormone gene (Hammer et al., 1984). Genetic differences in testicular size, number of LH receptors, and testosterone production also exist among inbred strains of mice but differences for these 3 variables were not consistently correlated among lines (Bartke \& Shire, 1972; Shire \& Bartke, 1972; Stalvey \& Payne, 1983).

Within a species, testicular weight during the breeding season is highly correlated with sperm production (for review, see Amann, 1970). The seminiferous tubules and contents are the primary contributor to mouse testicular weight (Eschenbrenner et al., 1948). Either a decreased length of seminiferous tubules or a decreased density of elements within a given length including decreased density due to degeneration of spermatogenic elements would affect testes weight. Since sperm production/g testis was similar in control lines, in the growth background, and in the presence of the $h g$ gene in the control background, decreased density of elements within the seminiferous tubule is unlikely to be the primary cause of the decreased testes size. A decreased length of seminiferous tubules implies either fewer spermatogonial stem cells or a lower mitotic activity of these stem cells.

In this study, selection for growth in mice resulted in reduced absolute testicular size as well as relative testicular size. A single recessive gene with a positive effect on somatic growth and/or closely linked genes also reduced absolute testicular weight and/or relative testicular weight. Decreased absolute size of testes resulting in decreased sperm production per mouse contributed to 
reduced male reproductive capacity in 2 of the growth lines. These lines provide a model system to study determinants of testicular size distinct from general effects on body size and spermatogenic efficiency.

\section{References}

Allrich, R.D., Wang, C.T., Dickerson, G.E. \& Zimmerman, D.R. (1981) Selection for increased rate or efficiency of lean growth in rats: correlated responses in reproductive performance. J. Anim. Sci. 53, 1458-1464.

Amann, R.P. (1970) Sperm production rates. In The Testis, pp. 433-482. Eds A. D. Johnson, W. R. Gomes \& N. L. VanDemark. Academic Press, New York.

Amann, R.P. \& Lambiase, J.T., Jr (1969) The male rabbit. III. Determination of daily sperm production by means of testicular homogenates. J. Anim. Sci. 28, 369-374.

Bartke, A. \& Shire, J.G.M. (1972) Differences between mouse strains in testicular cholesterol levels and androgen target organs. J. Endocr. 55, 173-184.

Bradford, G.E. (1971) Growth and reproduction in mice selected for rapid body weight gain. Genetics, Princeton 69, 499-512.

Bradford, G.E. \& Famula, T.R. (1984) Evidence for a major gene for rapid postweaning growth in mice. Genet. Res., Camb. 44, 293-308.

Calvert, C.C., Famula, T.R., Bernier, J.F. \& Bradford, G.E. (1985) Serial composition during growth in mice with a major gene for rapid postweaning growth. Growth 49, 246-257.

Calvert, C.C., Famula, T.R., Bernier, J.F., Khalaf, N. \& Bradford, G.E. (1986) Efficiency of growth in mice with a major gene for rapid postweaning gain. $J$. Anim. Sci. 62, 77-85.

Campbell, G.A., Kurcz, M., Marshall, S. \& Meites, J. (1977) Effects of starvation in rats on serum levels of follicle stimulating hormone, luteinizing hormone, thyrotropin, growth hormone and prolactin; response to LH-releasing hormone and thyrotropinreleasing hormone. Endocrinology 100, 580-587.

Chubb, C. \& Nolan, C. (1985) Animal models of male infertility: mice bearing single-gene mutations that induce infertility. Endocrinology 117, 338-346.

Dilts, R.B. (1988) Ovulation rate and pre- and postimplantation survival in mice with a major gene for postweaning growth. M.S. thesis, University of California, Davis.

Eisen, E.J. \& Johnson, B.H. (1981) Correlated responses in male reproductive traits in mice selected for litter size and body weight. Genetics, Princeton 99, $513-524$.

Eschenbrenner, A.B., Miller, E. \& Lorenz, E. (1948) Quantitative histologic analysis of the effect of chronic whole body irradiation with gamma rays on the spermatogenic elements and the interstitial tissue of the testes of mice. J. natn. Cancer Inst. 9, 133-147.

Famula, T.R., Calvert, C.C. \& Bradford, G.E. (1986) The major gene for rapid postweaning growth in mice: a review. Proc. 3rd Wld Congr. Genetics Applied to Livestock Production XI, 383-388.
Fowler, R.E. \& Edwards, R.G. (1960) The fertility of mice selected for large or small body size. Genet. Res., Camb. 1, 393-407.

Frisch, R.E. (1980) Pubertal adipose tissue: is it necessary for normal sexual maturation? Evidence from the rat and human female. Fedn Proc. Fedn Am. Socs exp. Biol. 39, 2395-2399.

Glass, A.R., Mellitt, R., Vigersky, R.A. \& Swerdloff, R.S. (1979) Hypoandrogenism and abnormal regulation of gonadotropin secretion in rats fed a low protein diet. Endocrinology. 104, 438-442.

Hammer, R.E., Palmiter, R.D. \& Brinster, R.L. (1984) Partial correction of murine hereditary growth disorder by germ-line incorporation of a new gene. Nature, Lond. 311, 65-67.

Islam, A.B.M.M., Hill, W.G. \& Land, R.B. (1976) Ovulation rate of lines of mice selected for testis weight. Genet. Res., Camb. 27, 23-32.

Kenagy, G.J. \& Trombulak, S.C. (1986) Size and function of mammalian testes in relation to body size. $J$. Mammal. 67, 1-22.

Joakimsen, O. \& Baker, R.L. (1977) Selection for litter size in mice. Acta agricult. scand. 27, 301-318.

Land, R.B. (1973) The expression of female sex-limited characters in the male. Nature, Lond. 241, 208-209.

Land, R.B. \& Carr, W.R. (1975) Testis growth and plasma LH concentration following hemicastration and its relation with female prolificacy in sheep. $J$. Reprod. Fert. 45, 495-501.

Phillips, R.W. \& Zeller, J.H. (1943) Sexual development in small and large types of swine. Anat. Rec. 85, $387-400$.

Roberts, R.C. (1979) Side effects of selection for growth in laboratory animals. Livest. Prod. Sci. 6, 93-104.

Schinckel, A., Johnson, R.K., Pumfrey, R.A. \& Zimmerman, D.R. (1983) Testicular growth in boars of different genetic lines and its relationship to reproductive performamce. J. Anim. Sci. 56, 1065-1076.

Setchell, B.P. (1978) The Mammalian Testis. P. Elek, London.

Shire, J.G.M. \& Bartke, A. (1972) Strain differences in testicular weight and spermatogenesis with special reference to $\mathrm{C} 57 \mathrm{BL} / 10 \mathrm{~J}$ and DBA/2J mice. J. Endocr. $55,163-171$.

Stalvey, J.R.D. \& Payne, A.H. (1983) Luteinizing hormone receptors and testosterone production in whole testes and purified Leydig cells from the mouse: differences among inbred strains. Endocrinology 112, 1696-1701.

Wolfe, H.G., Bartke, A., Amador, A., Van Sickle, M., Dalterio, S. \& Brown, D. (1981) Testicular function in strains of mice selected for differences in gonadotrophin-induced ovulation rate. J. Endocr. 90, $367-373$. 